Thapa, M.B.

1990

People's Participation in Range Management : The Case of Mustang, Nepal. Unpublished MS Thesis in Rural Sociology. University of Philippines at Las Banos.

Upadhaya, S.R.P

1995

Nepals' Social, Economic and Administrative History Ratna Pustak Bhandar, Kathmandu, Nepal.

Von Furer-Haimendorf, C.

1975 Himalayan Traders. John Murray, London.

Wilson, $\mathrm{P}$.

1981

Ecology and Habitat Utilization of Blue Sheep in Nepal. Biological Conservation. 21:55-74.

Mc VEigh, C. 1994
Indigenous Resource Management Systems Among the Tibetan-speaking Herders in Western Nepal. Research Report Submitted USAID Nepal Mission, Kathmandu, Nepal.

\section{EMERGING METHODS IN RESEARCH PARTICIPATION AND EMPOWERMENT PROCESSES IN NEPAL}

Philip Tanner*

\section{Introduction}

This paper is divided into two discussions. Firstly, it traces the development of participatory processes and policy in Nepal's development evolution over the past 40 years. Secondly, it examines, briefly, the developments in international social research and emerging knowledge on the subject of participation and empowerment concepts that may influence the direction of social research in Nepal.

\section{The Emergence of Participation in Nepal}

At the time of Nepal's emergence onto the global scene, over $93 \%$ of its population earned its livelihood from the land. The new rulers, after 1951, were eager to project themselves as the champion of the poor, the downtrodden and the oppressed (Lohani, 1978) and discussion of "democracy" abounded. Struggling to develop a comprehensive development plan, it was clear that most effort had to focus on rural and agricultural development programmes. However, by 1979, a study on Nepal's agrarian problems described the strategies and programmes for their solution as "merely a survival strategy" (Blaikie, M, Cameron, J \& Seddon, D., 1979). Clearly, the efforts of the state were not directly manifest in field practice. Generally, there was acceptance in Nepal's academic and government community that rural development efforts

Dr. Philip Tanner worked for UNDP in Nepal from 1990-92 and subsequently carried out extensive research in Nepal during the period of 1993-1997 on the relationship of Empowerment and Participatory development concepts in Nepal. He is now working in a development INGO in Nepal. This is the first in a series of articles on empowermnet theory in the Nepali context 
(principally through RD and IRD approaches) had failed to show positive results (UN, 1990). Large influx of monetary support and development assistance realized success in isolated pockets but there was no "breakthrough". For the first two decades in Nepal's development programme, therefore, something was clearly missing.

The investigation into Nepal's basic needs strategy, by Integrated Development Systems/Nepal at Tribhuvan University suggested that programmes must aim to provide the deprived and poor with the means to escape from their deprivation and poverty...through their own involvement in the process of development...and control over the conditions under which deprivation and poverty are generated (Integrated Development Studies, 1985). The authors were not only pointing out the deficiency in Nepal's development programme (there being, until recently, very little tradition or history of planning in Nepal, before 1951 - Shrestha, 1989) but were also pointing a finger at the limited commitment of the Nepal government to this type of approach (Blaike et al., op cit:25).

Blaikie et al., centred on Marxist dependency theory in an effort to point out the exploitation of the peripheral regions of Nepal by Kathmandu, asking the question, "will the centre permit villagers to enter into the development process (Ibid, 1979:42). Shepherd (1982) raised similar questions and pointed out the principal failure of participation as the absence of rapport and understanding between local people and the officials in government. While the rhetoric was relatively new, the notion of "participation" has not been a recent phenomenon in Nepal; although it has been manifested in varying ways. Nepal's planning era began in 1956 and has had 8 planning periods of 5 years that have emphasised rural development, local development and participatory planning, to varying degrees. It is helpful to look at the early evolution of participatory planning and policy in Nepal, between 1956 and 1980 (looking specifically at the 5-year plans) and then the changes between 1980 and the present, which paved the way to Nepal's modern practice of democratic and decentralized development policy.

\section{Policy Change}

Some of the critical paths taken in participatory methods and policy, strode hang-in-hand with both academic development around the world and current political and academic trends in Nepal, itself. These developments were particularly evident through the first 5 development plans undertaken in the Kingdom. As early as Nepal's first development plan (1956/61), there was also the first official statement that separated "village development" from a macro development strategy for the country as a whole and emphasised the active involvement and cooperation of the people in rural development. Rural development (RD) plans were set into motion and co-operatives were, in particular, stressed as important to the RD objectives. However, the achievement of the first plan was considered very poor, viewed as ambitious and with no clear objectives and policy (Pokharel, 1980). Pokharel referred to the plan as an "arm-chair plan," with no facts and figures and no field research to evaluate progress. By the second plan (1961/65), a radical political change had occurred in the country. The King had assumed all political powers and dissolved the parliamentary constitution. It was at this point that the Panchayat system was introduced together with a greater degree of control of organizations and institutions throughout the country. Rural development ceased to be treated as a separate entity and was, instead, considered synonymous with agricultural development. In essence, this shifted the emphasis from a programme-oriented area approach to the sectoral approach of rural development. People's participation was again on the agenda, although tightly controlled by the government. The village panchayats, heavily politicized, were the local institutions available for local people, acting as the political and developmental unit at the grassroots level. In 1962 the constitution had specifically supported "participation", stating that "development of the country is possible only... with the active co-operation of the whole people, and embodying the principles of de-centralization" (Shrestha, 1981:172). The constitution sought, in theory, to "make the general public vigilant and conscious through gradual de-centralization and to 
provide for maximum participation in the economic uplifting of the country (Joshi, 1983:85)

The Third Five Year Plan (1965/70:273) focussed the notion of "people" even more clearly. It stated that, "all citizens may have equal opportunities and facilities to develop their personality and to enhance their economic progress." The Panchayat system was maintained as the best vehicle for people to achieve this goal and necessary for the political, social and economic growth of the nation (Pokharel, 1980). Rural development again took a side-line to the overall plan, making reference only to "regional development" (no doubt a prerequisite for rural development), "boosting food production in the Terai", "horticulture in the hills" and "animal husbandry" in the mountains. The Panchayats were entrusted to conduct local development throughout the nation.

It was, perhaps, during the Fourth Five Year Plan (1970/75), that the most serious changes in rural development and people's participation occurred. It was during this period that one of the first Integrated Rural Development (IRD) programmes was introduced in the form of the "Jiri Multipurpose Development Project.: a package of inputs to improve the economic and social life of the rural poor (Lohani, $1980: 4^{\text {th }}$ Plan:263). The fourth plan placed high emphasis on regional planning without specific reference to rural development. It mentioned people's participation in the policy section, stating that "attempts will be made to get the panchayats of various levels involved more effectively in the process both for plan formulation and implementation, in order to make the participation of the people in the local development work more active and dynamic ( $4^{\text {th }}$ Plan:254).

The Fifth Plan (1976/80) was aimed at utilizing human resources, placing renewed emphasis on people's participation and calling for the involvement of the local people in development projects (controlled and conducted by the local panchayats) However, in the absence of a well-defined institutional framework to enlist the participation of the beneficiaries, the various rural development efforts did not successfully achieve the desired results (UN, 1990:19; Joshi, 1980, in Rising Nepal Newspaper). Since 1976, several IRDP's had been implemented across the country, leading to increased involvement of people in infrastructural projects, skills training programmes, distribution and experimentation. However, by $1985 / 86$, the National Planning Commission (NPC) indicated that $43 \%$ of rural poor were still below the poverty line and malnutrition remained a serious problem. The principal reasons for the failure of IRDPs was (a) the government did not allow the panchayats to determine local priorities, (b) beneficiaries were not aware of target activities, (c) while de-centralization supported local institutions (in theory), the policies and priorities and budget were determined at the centre and dictated, (d) poor completion of technical projects, chosen by the poor, created a suscpicion in rural communities that the government was ingnoring their demands and (e) the benefits of development were being exploited by the powerful (particularly those involved with the panchayat institutions (UN, 1990). The basic premise, therefore, was that while participation was growing in the official rhetoric, there was no real chance of seeking full participation in the present political climate of the country. In particular, low-caste farmers were reticent to antagonize highcaste farmers. While the government spoke of closer cooperation between the panchayats and local people, insufficient power was given to them and what little power they had, they tended to wield over the poor rather than facilitate improvements for them (Gautam, 1987).

Until the end of the Fifth plan (1980), several key policies had been implemented, despite their apparent deficiency is addressing the key issues related to local development and and participation. These were: the Local Administration Act of 1966, the District Administrative Plan of 1974 and the Integrated Panchayat Development Design of 1978. The latter defined "rural development" under the auspices of "Panchayat Development" (Shrestha, 1981), and emphasised popular participation and exploitation of local resources. This was the first policy implementation which laid out the objective of participatory involvement in development affairs and a new 
position of Local Development Officer (LDO) was created to facilitate development at the grassroots level. However, at this time, the government was reluctant to concede de-centralization as a means to the purpose of local development (Poudyal, 1987). It was not until the De-centralization Act of 1982 that the two notions were pulled together into a singular policy initiative (Ibid., 1987:16). The Act aimed to ensure participation in development initiatives and to maintain and improve capabilities for the institutionalization of development activities (Poudyal, 1991). However, that is not to imply that participatory activities did not exist before the De-Centralization Act. Indeed, casestudies can be found in the literature concerning various hill irrigation projects which involved farmers in the development, operation and maintenance of irrigation systems (See, Martin \& Yoder, 1983: Case-studies "Thulo-Khola" Irrigation System, Halung and others; Integrated Development Systems/Nepal, 1986). It was not until the de-centralization act, however, that the government recognized that people's participation was both a method and an objective (means and end) of rural development programmes in Nepal and that it can be facilitated through a policy of de-centralization (Shrestha, 1981:171).

\section{Academic Rhetoric - The Local Reaction}

Increased activity by Nepal academics was also indicative of the country's recent emergence into the global community and modern development practice. The poor use of field research and practical study was a hinderance to government policy as there was little local, academic resources upon which to draw. As late as the mid-1970's, sociological research in Nepal was often described as "patchy and sketchy" (Bista, 1972). Speaking at a conference in 1973, Bista remarked that up to the mid-1970's, anthropology was totally unknown and few empirical works had been done. In addition, local studies had tended to focus on central and Eastern Nepal, leaving the greater part of the Western Region largely unknown and unexplored (Furer-Haimendorf, 1973). While geography and topography played a role in this selection, some Nepali scholars (Bista, 1973; Shrestha, 1971; Mishra, 1984) suggested that there was also influence due to inherent biases between groups in Nepal, which often inhibited Nepali scholars (most of whom were High caste) from studying in communities that constituted predominantly low caste groups. The 1973 conference conceded that there was, at that time, more benefit to be attained from foreign researchers transcending cultural and traditional norms and carrying out this type of scholastic work. However, such research did not get underway until well into the late 60 's and early 70 's and even then, Nepali researchers complained that the results of the research were often taken away from the country and provided very little feed-back or useful data that may have been applied to policy or implementation initiatives (Thapa, 1973). In addition, foreign research brought its own interpretations and biases to Nepal.

\section{Academic Rhetoric - The Foreign Reaction}

The claims of neo-classical economists that they could theoretically demonstrate efficiency, equity and stability outcomes from the operation of market forces, were central to the 1980's practice of the IMF globally, and more importantly for Nepal, the World Bank and many bilateral official development agencies (Cameron, 1994; Lipton, 1987) played key roles. The Nepali state was primarily seen as a problem to, not an agent of development. Intervention by the Nepalese state in restricting the operation of free market forces (some neoclassical economists suggested) was arguably the primary obstacle to the Nepalese people finding their natural position in the global economy. However, limitations on the neo-liberalism of the late 80 's revolved around the replacement of the nonmeasurable goals such as quality of life and human development. These goals were consigned to the subjective judgement, not accessible for policy consideration (Cameron, 1994). These limitations are discussed extensively by O'Connior (1987), Blaikie, Cameron and Seddon (1979), Higgins (1987) and Sen (1987). The popular struggles in the 1980's and early 1990's, therefore, brought a sense of opportunity and optimism to the post-modernists. The alternative approach, arising in global and local forms, expressed disatisfaction with the methodologies and 
epistemological framework of earlier debates. Fragmentation, as an approach to social reality in the 1990 's, was celebrated, rather than the previous totality theories (Cameron, 1994:78). This approach essentially set the stage for theoretical debate and practice on "specific issues, localised experiences, cultural dimension and power relations (Cameron, 1985).

Nepal has certainly felt the pressure and has experienced the change of shifting international fashions in development theory over the past 20 years. Cameron (Ibid.) describes these changes as altering the "development focus", giving a new image to Nepal. The progress through the early 1980 's, he states, has been more "sound and fury" than particularly useful. However, the changes in Nepal's political and social environment since the mid-80's is significant and it's impact on the role of people in their own development is equally impressive.

\section{Policy Meets Rhetoric}

Under the new system of de-centralization, from 1982, participation in Nepal began to be recognized as an active process, meaning that the groups in question could "take initiatives or assert their autonomy to do so" (Rahman, 1981:3). Both the academic world and policy makers were becoming more vigilant about participatory rhetoric in the 1980's and a number of local studies began addressing the deficiencies in people's participation, despite the wide-sweeping reforms, and also suggested remedies (Lohani, 1980; Pokharel, 1980; Joshi, 1983; Gautam, 1987; Shrestha, 1981). By 1984, it was becoming apparent to foreign and Nepali academics and officials, that participation was a process that accelerated if the poor become conscious of their rights and privileges and could build up faith and confidence in themselves. Integrated Development Systems/Nepal, 1985; Shrestha, 1989). In other words, success would be based on democracy and decentralization of power (Malhotra, 1990). By the end of the 1980 's period, the literature on Nepal reflected that for development to be self-sustaining, initiatives in rural development must come from within the communities (Ibid., 1990:10). However, until democracy, in 1990, there was little institutional support to nurture the process that had struggled to emerge through the last 15 years of development efforts in the country.

Hobley (1996) indicates that practical experience in the forestry sector of Nepal shows the close relationship between the emergence of democracy as a form of governance and the growing demand for its application to the management of forest resources (see also, Lohani, 1978). She goes on to state that "forestry" is significant in illustrating the 3 major trends in Nepal which have lead to true and equitable participation. First, there was systematic alienation of the general population. Second, the environmental degradation became extremely severe and led the government to exclude people and implement strict protectionist and nationalization policies (Hobley, 1996; Op. Cit., 1978:146). Thirdly, lack of control over the resources and an inability to resolve the environmental problems under the centrally controlled regime, led to an accommodation between the state and the people (see also, Bartlett, 1991and Ingles \& Gilmour, 1989). In short, participatory programmes would involve the people and yet allow a level of government involvement in the process. This final stage, leading to participatory involvement, is characterized by (a) an assertion of people's rights, (b) institutionalized expression of these rights and (c) a challenge to the current development paradigm, where demand for rights is a pursuit of power but linked to responsible land use. This was also pointed out by Dunsmore (1988), concerning mountain environmental management in the Arun River Basin of Nepal.

In a wider context, throughout the 1970's, however, concern was raised over finite global resource availability and notably non-renewable energy sources after a sharp rise in oil prices. The prioritisation of the ecological dimension also promoted examination of value systems and thus, the cultural dimension of development (Cameron, 1994:76). According to Cameron, these concerns altered the agenda for North-South discussion on development as well as for national development strategies, notably for Nepal which scored high on all the ecological vulnerability indices. Project documents outlined the need for participation, user-groups and local institutions, for 
successful environmental management and sustainable production. However, the success of the institutions in Nepal now depends on equitable, participatory relationships, which can only be sustained in a democratic and responsive political environment. Beneficiaries, it is recognized and accepted by the government, should be involved in the decision-making process. This was stated as a major cause of failure in the "Swayambhu Area Development Project in 1986 (Malla \& Rajbhandari, 1986). Despite the massive infusion of foreign aid, it became accepted that this aid would not result in development unless the individual farmer decided that it would (Miller, 1990). In essence, therefore, King Mahendra's speech in December of 1981 was being put into action; decision-making should be given to the "lowest units of our social structure".

\section{Recent Trends}

With the introduction of a democratic constitution and constitutional monarchy in 1990, parliament passed the "laws of local governance". In May 1992, democratic multi-party elections were held for local authorities and 45,000 persons were directly elected to village and town councils throughout the nation. Since that time, the process has continued to strengthen and develop with the support of the government and financial backing of many development agencies, giving the mass of people the opportunity to make locally-based decisions concerning development matters. There appears to be a general acceptance in the government for the principle of "voice" and "choice", as operational norms. Voice referring to the right to criticize the government's handling of development design and implementation. Choice referring to the liberalization of development, providing people with alternative options to choose external assistance as well as to implement projects (e.g. government or non-government sources of assistance).

The official justification for decentralization in Nepal has been to increase local participation in planning and implementing development strategies, to mobilize local resources and to increase accountability of officials to citizens. The phrase commonly used in agency project (Tanner, 2001) documents is a variation on the theme of "empowering" local people by enabling their right to participate freely in decisionmaking processes. Officially, this is accomplished through the delegation of power to local administrative agencies. However, due to weak cooperation among ministries at the national level, local rural development policies are often undermined and local participation, according to Beinen et al. (1990) is still participation controlled by the higher levels of authority.

The devolution of power to local authorities is strongly supported at the present time. Under the country's eighth plan (HMG 8th Plan, 1992-97: 652), the government recognizes that a centralized approach to development planning has not been effective and is not the best way to achieve economic development in Nepal. Instead, HMG has outlined very clearly that the public should be mobilized for participation and be allowed to implement programmes at their own pace; including opportunities for decision-making. "The local people themselves need to be involved more actively both at the planning and execution level" (op cit.575). Through a strategy of delegating authority to popularly mandated village and district authorities, the government hopes to (1) promote sustainable economic growth, (2) alleviate poverty and, (3) obtain regional balance. The main activity is to implement a sustainable and participatory approach to rural development encompassing "economic, political/governmental, social, cultural/religious, and educational dimensions". In HMGs 8th Plan (op cit: 579), the fifth objective for local development is:

"To create a base for sustainable development by maximizing peoples' participation in rural development works."

The districts that have the support of agencies like UNDP, have been institutionalizing a participatory and multi-sectorial oriented planning and monitoring system for management of district development (e.g. Management Information Systems and Geographic Information Systems). The apparent success in these districts has been reflected in the promotion of improved information sharing from the local level up to the national level. The planning approach has created an environment for better coordination of sectoral efforts and resource management in 
which (a) needs are identified by the communities themselves (through local institutions, preferably) and, (b) projects are selected through a process of prioritization. These activities are coordinated by the DDC in collaboration with the sectoral agencies. One of the first of-springs of this plan was manifested in the "Build-Your-Own-Village" campaign, introduced in 1995 with a budget of three million Nepalese Rupees (USD 53,571) per annum to each VDC. The purpose of this programme was to (1) reduce the dependency of the VDC development process from the "central-oriented" control of the DDCs, (2) provide moral support for more effective participation of the VDCs in the deliberations of the District Council (3) enhance local level decision-making, (4) use local skills and resources and (5) bring about a much needed awareness that the people should take a lead in their own development. Ideally, this budget was not "tied" and VDC committees could use it in any manner without the consent of higher bodies. Although the amount of funds allocated may not be sufficient to make substantial improvements in entire VDCs, it does create a psychological "perception" of control within the VDC development regions. While we will not discuss the positive or negative sides of this scheme, it is important to note that this "perception," perhaps, has contributed the most to empowerment of these regions. In addition, small projects and rehabilitation schemes could be undertaken without the bureaucratic requirements associated with most development initiatives.

Since the beginning of the 1990's, the focus of community development and social work literature has shifted to the individual as "subject" of investigation. Nepal has been no exception to this trend. Pokharel (1980) and Manandhar (1992) had argued that the "outside view of villagers is different from the inside view of themselves", Shrestha (1989) discussed the need for giving a "voice" to individuals, Pokharel (1980) introduced the concepts of "faith", "confidence" and "effectiveness" building in order to solve local problems and Miller (1990) discussed the importance of understanding the process of decision-making for "heads of households" in order to grasp the roots of decision-making within an individual's and household's life-space. ${ }^{1}$ Integrated Development Systems/Nepal $(1985: 4)$ published an article which called for studies in Nepal that "seek to complement the de-centralized efforts and to raise people's awareness of opportunities," describing consciousness as a "function of action." Manandhar (1992:35) went further to explicitly state that the main task of development in Nepal must be to "nurture the individual," encouraging involvement and participation. The individual, he states, should be at the "centre."

Manandhar's philosophy on the individual stemmed from the early rhetoric of Mahatma Ghandi, which had great influence over much of the Hindhu populations. Ghandi argued in favour of self-reliance, through peaceful activism. His ideas, in particular, targeted the "individual" and his "community." The development of India, he said, was supported by the development of thousands of small villages across India. To govern the individual, is to govern the community, is to govern the region, which is to govern the state (in, Manandhar, 1992:35). However, Ghandi was similarly influenced by the even earlier movement of Swaraj, which was based on the premise of beginning with the "individual" and moving to the "state." To this end, some academics within the newly democratic environment of Nepal, have initiated studies which examine "attitudes", "priorities" and "perceptions" of individuals in village communities. In addition, there has been an obvious shift in the changing roles of technical expertise from outside and in Nepali experts and, in the methods employed to conduct field research. Findings indicate (Chambers, 1991) that rural people can manifest greater analytical capabilities and can effect positive developmental change. The technology now most needed is "methodological" - to change personal attitudes, demeanor and methods. There is a wealth of literature on this subject, furthering the notion that the individual stands firmly at the centre of development policy and initiatives.

\footnotetext{
${ }^{1}$ The latter work is a somewhat earlier version of Friedman's (1992) discussion of household economies and empowerment structures.
} 


\section{Future Directions}

It could be said that the advent of capitalism and modernity replaced all structures that were based on "subjective," or "irrational," elements, with "objective" and "rational" science (Vandergeest \& Buttel, 1988). However, this view is changing in both rhetoric and practice. Many schools of thought have firmly centred on the methodology of the "individual" as the object of social inquiry. Weber stated that it was only the individual who could be studied "meaningfully". This is evident in his method called Verstehen (Parkin, 1982). The premise of Verstehen, which centres around social actors who are faced with choices, was proposed as a means of understanding historical events through the eyes of the actors in an empathic manner. In this way, the researcher identifies why certain paths are followed based on a reconstruction of situational choices and constraints that face individuals (see also Friedman, 1995). The decisions that are taken are based on the actor's perceptions that are weighed and assessed as the research progresses. In "profit-maximization", there is both a behavioural content (motivation of the household) and technical- economic content (farm economic performances as a business enterprise). However, the former is usually only inferred through investigation of the latter (Ellis, 1988:64).

Parkin (1982) points out that Weber's Verstehen proceeded from the principle that people are generally aware of their perceptions and subjective thoughts. If these perceptions are truly integral to social conduct, then, as Parker asserts, they must be accepted as "givens" in their own right (Berger and Luckman, 1966, describe them as "social facts"). This does not appear to leave room for Marx's concept of a false consciousness. Marx stated that true perceptions and meanings are largely congruent with an individual's class interests but that due to the intrusion of the bourgeois ideology, the average individual's perceptions tend to be quite faulty. Thus, viewing reality through the actor, in the way posited by Weber, would provide a false or twisted version of that reality.
Durkheim differs from Weber (as does Marx) in that he emphasizes the need to study the collective. He states that studying the individual motives and perceptions, as principal objects of inquiry, would be to forfeit everything of sociological interest (Parkin, 1982). Weber, in contrast, feels that it is the role of social science to penetrate the subjective understandings of the individual, to get at the motives for social action. Collectives, he feels, must be treated solely as the resultants and modes of organization of the particular acts of individual persons. To put it more simply, the process might be compared to a chemical reaction in which one party views the resultant compound as important in itself, while the other party examines the importance of the ingredient elements.

\section{The New Sociology of Knowledge - Methods in Research}

Lewin (1946) recognized, 50 years ago, a need for a novel approach to research in the social sciences which would simultaneously solve problems and generate new knowledge. These ideas have helped initiate the new field of applied social psychology, action research and more recently, participatory research; which now play an important role in helping us to define social issues (Yeich and Levine, 1992) and which appear to take issue with the traditionalist school of development theory. This approach to sociological research emerged as a result of two broad forces: (1) researchers found that the classical research paradigm was insufficient, oppressive and elitist (Gaventa, 1980; Hall, 1981); lacking the necessary insight and sensitivity to human issues which is increasingly characteristic of the new discourse, and (2) recognition of the continuing potential for exploitation of the many, caused by the monopoly of knowledge by the powerful few (Toffler, 1990).

Knowledge has rapidly emerged as a significant influence in the new paradigm. In the past, concentration of knowledge in the hands of the few has led to the occlusion of power from disenfranchised groups. With the advent of alternative development methods, we are now seeing the reversal of this trend, placing emphasis on knowledge in the hands of 
those suppressed groups and bringing such knowledge to "awareness"; thus allowing people to become conscious that they indeed have the necessary skills and insight to exert themselves and become self-sufficient. Friere (1973) made a significant contribution in this regard, maintaining that marginalized people will remain dependent on others for as long as they fail to be conscious of their own power to address problems. In addition, he emphasizes that these people are capable of critical thought and can engage in the dialogue surrounding their own development. This latter assertion has become an important assumption in the discussion of empowerment theory and supports the notion that the individual is an important subject of inquiry and social action. Illich (1976:148) argued that the concept of underdevelopment, in addition to "physical impoverishment", was also a state of mind. Many would agree that understanding underdevelopment at that level is important to bringing about change. A commitment to contemporary processes, such as "Participation", arose out of the changes in the last several decades, requiring, implicitly, attention to the constraints and contextual barriers facing the resource-poor - it also implies "powerlessness" or an inability to exert influence to shape one's livelihood.

\section{Empowerment Emerging from the New Discourse}

The "project", as most field officers who were interviewed reported, tries to breathe "empowerment" into the community. This does not mean that the project empowers the community but rather that it facilitates approaches that lead individuals to become empowered. The struggle to re-design development programmes to address these concerns continues with heavy emphasis on the role of the resource-poor in the development process. The classical thoeries of development are not discardded but are modified in order to envelop concerns that had hitherto been inferred or ignored.

Since the 1980's, theories have arisen which retain study at the individual level but with a new premise and methodology. In addition, case studies have assisted in the construction of a more coherent view of empowerment that takes into account, (a) community issues, (b) structural/ institutional aspects and, (c) individual-community dynamics. These studies have led to the development of what has been called, Learned Hopefulness Theory, demonstrating that people can work towards social change despite seemingly insurmountable obstacles. The latter work examines the process of mobilizing individuals and groups for purposes of creating socio-structural change to benefit oppressed people (Yeich \& Levine, 1992). This notion implies a recognition of structural forces which affect, if not cause, social problems, instead of resignation to an oppressive environment by the masses. The objective is to identify the problems within and outside the community (Yeich \& Levine, 1992; Zimmerman, 1992; Zimmerman, 1990; Wandersman, Florin, Rich \& Chavis, 1990). This latter objective may direct the focus of research to the positive consequences of exerting control (through participation). Examination could also be made of the process of learning and utilizing problem-solving skills (acquired during participation), which result in the achievement of further perceived or actual control. Studies indicate that efforts to exert control through participation, should increase one's sense of empowerment through a responsive framework; in other words, enhancing the individual's ability to understand and increase his/her control over the environment through interaction.

It is critical, when considering the above statements, to note that the process goes beyond traditional notions of human deficits. The principle goal of complete empowerment research today - an essentially psychological state in its primordial form should include (a) developing an awareness of a social construct of reality' in the actors, (b) a recognition of the oppressive nature of the social construct, (c) an acknowledgment of the necessity for skills and tool development to effect change and, (d) an awareness of the multiple layers of interaction which occur within and outside the community which will affect the way that its members relate and participate within that community.

The methodology described above is based on several additional key assumptions and provides a platform upon which this research is based: 
1. People generally know what is best for them (cf., also, Oakley, 1983).

2. All people are experts in certain areas of their lives (including Indigenous Technical Knowledge).

3. All people have strengths on which to build.

4. All people have skills to be learned and shared (often through local institutions). (Torre, 1989; Zimmerman \& Rappaport, 1988)

5. People have the ability to think critically about world affairs (including local, regional and national issues) and to ascertain their own position within their environment (Friere, 1970).

6. People can take reflective action, directed toward responsible social change. This involves the development of necessary skills to interact and respond, in relation to the political and economic environment.

In general, it is evident that empowerment and learned hopefulness theory revolve around several important themes. The latter theory relates to (a) people's ability to develop and their ability to become educated, (b) the nature of education within the development process, (c) the importance of personal associations, formed either purposely or by happenstance (these associations have been referred to as mediating structures and collectives; Torre, 1989), (d) the relationship between personal associations and macro system structures (political, economic and social systems) and finally, (e) the nature and use of power within the empowerment process. It should be acknowledged, of course, that not everyone adheres to the "Frierian" notion of an "educational" prelude to people being able to look after their own destiny. Others have argued that people are perfectly able to express needs and do something about them, if given the opportunity (see Curtis in Neilson \& Wright, 1995). Friere's concept of education is widely held in non-governmental circles, however, and it is in this circle that much of the "alternative development" literature and concepts are revived and implemented.

In short, the goals of empowerment have changed from the deficit-oriented methodology of learned helplessness, to a fuller understanding of how an individual's perceptions /cognitions interact with events in his/her environment to enhance or inhibit his/her control over the "factors" that affect his/her life (Zimmerman, 1992). These latter may range from coping with personal problems and decisions affecting the household to those wider activities relating to community or state issues. The described goals relate directly to the way in which individuals, communities or ethnic groups attempt to express themselves or exert their influence within their environment. Most important in the notion of empowerment and learned hopefulness theory is the protection of the valuable knowledge already extant in the individual or group to (a) a blossoming awareness of that knowledge, and finally (b) "putting that knowledge to work" (through positive and non-violent initiatives).

\section{Comments}

At present, there are limited reliable or tested means by which participatory and empowerment project implementation and the new subject of study (the individual) can be evaluated; particularly in "subjective" project planning and implementation. With the evolution from strict "blue-print" guidelines for project implementation (in which "rigidity" does not allow for flexible project planning and hence, tools), to a more "process-oriented" approach, development tools to monitor and evaluate every step within the project freamework, becomes ever more important (Tanner, 2000).

It was noted earlier that much research is conducted to the benefit of the researcher. Nepali scholars, also, have noted that this has been a difficult problem in their country (Bista, 1973; Thapa, 1973). Pure research often does not involve people and it contributes only a little sympathy and interest in the host country or for the community(ies) studied. For the most part, the people in the sample groups do not understand what is being done and have no direct part to play in the process or end product. It is a fault of many aspects of research, in general. The results of many studies are not obviously relevant to a farmer's way of life, nor is it always apparent how s/he is 
involved or may benefit from either the process or results of a study. However, this should not nullify or preclude the need for research to advance methodology. Rather, it should place the onus on the researcher to determine the studies purpose and result; whether it is geared to mobilize people, achieve specific outputs, is the basis for future policy, or makes some contribution to the corpus of knowledge on a given subject, which may lead to any of the above.

Social research may not always lend itself to immediate, practical usefulness but the results do point to critical areas that could be of interest to policy-makers or those involved in experimental processes. In areas where scientific-style research can not offer complete explanations for the sources of dynamic and change within social relations, the need for social research obviously increases. The ultimate questions, therefore, to determine where ideas, values and idealism, altruism and cooperation, come from are, perhaps, beyond scientific reach. As Uphoff states, they have elements of both randomness and order, much the way market [commodity] price patterns or political conditions have. How individuals relate to their community and vice versa will create a cause and effect relationship, which create outcomes that are both predictable and indeterminate. However, they are not completely random. If they were, there would be no point in acting purposefully and no point in studying the area. Perhaps, therefore, the best that one can hope for is to understand the dynamics of behaviour within the limited framework of the "new (social) science". We accept the inherent "chaos" (Uphoff, 1992) in the patterns studied and attempt to apply qualitative and quantitative approaches to triangulate an approximation or probability of behaviour.

Within the above framework, it is clear that the importance attached to "scale" is important, because it breaks from the reductionist presumptions of conventional science that the whole is simply made up of its parts. Instead, wholes should be seen in relation to their parts, which are themselves wholes to be viewed in relation to their own part, and so on. This is not dissimilar to Ghandi's proposition that India's development is based upon the backs of individuals: Understanding the individual helps us to understand the community, which helps to understand the region and thus, the state. In the same vein, the study into empowerment and participatory activities may not begin with the assertion of macro-empowerment dynamics, although these levels exist. Instead, it begins with the individual and then branches out to the household, the community, the region and the state.

Nepal, as a nation, has generated invaluable data to advance the discourse in methodology and project implementation addressing participatory planning and empowerment of people. However, much of this data is externally driven and influenced by the pressures of outside schools of thought. There is a wealth of experience and data, though, that may be tapped and utilized to generate theory or partial theory by Nepali scholars and to contribute to the corpus of knowledge already extant in the international literature.

\section{REFERENCES}

Peter Burger and Thomas Luckman.

1966 The Social Construction of Reality: A Treatise in the Sociology of Knowledge. Garden City, NY: Doubleday, Ursinus: 301.01/B453s

Bienen, H., Kapur, D., Parks, J., Riedinger, J.

1990 Decentralization in Nepal. World Development, 18, No. 1, p.p. $61-75,1990$.

Bista, K.B.

1972

Le Culte de Kuldevata au Nepal en particulier chez certains Ksatri de la vallee de Kathmandu. Paris, Edition Nove.

Bista, K.B

1973 State of Anthropology in Nepal. Tribhuvan University. Kathmandu, Nepal.

Blaikie, M.P., Cameron, J. \& Seddon, D.

1979 The Struggle for Basic Needs in Nepal. Paris, Development Centre of the Organization for Economic Cooperation and Development, p. 42. 
Boeren, A. 1992

\section{Cameron, J}

1985

\section{Cameron, J}

1994

Chambers, $\mathrm{R}$

1991

Dunsmore, J.R

1988

Ellis, F.

1988

Friedman, J.

1992

Freire, $\mathrm{P}$.

1970

Freire, $\mathrm{P}$

1973

Furer-Haimendorf, C.V
Getting Involved: communication for participatory development, Community Development Journal, 27, pp. 259-271.

Destitute Allowance vs Family Assistance: Conflict Over Welfare Labels in Fiji, in Geoff Wood (ed), Labelling in Development Policy: Essays in honour of Bernard Schaffer, Sage.

Nepal's Development Thinking: Twenty year son in Theory and Practice. The Economic Journal of Nepal. Vol. 17(2), issue No. 66.

Complexity, Diversity and Competence: Toward Sustainable Livelihood from Farming Systems in the $21^{\text {st }}$ Century.: Journal of Asian Farming Systems Association, Vol. 1(1), pp. 79-89.

Mountain Environmental Management in the Arun River Basin of Nepal. ICIMOD Occasional Paper, no. 9. Kathmandu, Nepal.

Peasant Economics: Farm Households and Agrarian Development. Cambridge University Press, UK.

Empowerment: The Politics of Alternative Development. Blackwell Publishers, Cambridge, MA (USA), 1992, P.P. 1-189.

Pedagogy of the Oppressed. New York, N.Y.: The Continuum Publishing Corporation.

Education for Critical Consciousness. New York, N.Y.: Seabury.

Preliminary Report on Anthropological Research in Western Nepal. SOAS. Univesrity of London. March, 1973. (unpublished).
Gautam, U

Institution-building and Rural Development in Nepal: Gadkhar Water Users' Committee. HMGUSAID-GTZ-IDRC-Ford-Winrock Project. Natural Resource Management Paper Series. No. 8

Gaventa, J.

1980

Power and Powerlessness: Quiesience and Rebellion in an Appalachian Valley. Chicago: University of Illinois Press.

Hall, B.

1981

Participatory Research, Popular Knowledge, and Power: A Personal Reflection. Convergence, 14, 6-17.

Hobley, M.

1996

Higgins, B.

1987

Illich, I

1976

IDS

1985

IDS

1986

Joshi, J.

1980

Joshi, J.

1983
Participatory Forestry: The Process of Change in India and Nepal. ODI Rural Development Forestry Study Guide 3.

Economics and Ethics in the New Approach to Development, Philosophy in Context, 7.

Celebration of Awareness: A Call for Institutional Revolution. Pelican Books, p.p. 1-156.

Non-governmental Institutions and Processes for Development in Nepal. IDS, Kathmandu, Nepal, pp. 1-111.

People's Participation in Management and Performance of Irrigation Resources: A comparative assessment of government-operated and farmer-operated systems in Parsa District, Kathmandu, Nepal, pp. 1-115.

People's Participation and Rural Development. 1 The Rising Nepal, October 22

People Participation in Housing Development. The Journal of Development and Administration Studies. Vol 5(1), 1983, pp. 69-111. 
Lipton, M. A. 1987

Limits of Price Policy for Agriculture: Which Way for the World Bank", Development Policy Review, Vol. 5, Sage.

Lohani, P.C.

1978

People's Participation in Development. Kathmandu, Centre for Economic Development and Administration, Tribhuvan University.

Lohani, P.C.

1980

People's Participation in Development. Kathmandu: Centre for Economic Development and Administration, 1980.

Malhotra, R.C.

1990

A People-Oriented Proposal. Himal: For Development and Environment. May/June, 1990, p. 10.

Malla, B.C. \& Rajbhandari

1986 People's Participation in Development: A Case Study of Swayambhu Area. Centre for Economic Development and Administration, Nepal, pp. 1-95.

Manandhar, $\mathrm{R}$.

1992

Self-Reliance in Small Communities. Mohan Primlani for Oxford \& IBH Publishing Co., 1992. P.P. 2-279.

Miller, C.J.

1999

Decision-Making in Village Nepal. Sahayogi Press Pvt. Ltd. Tripureshwar, Nepal, pp. 1-168.

Mishra, Chaitnya

1984 Social Research in Nepal: A critique and a Proposal. Contributions to Nepalese Studies. Volume 11(2), pp. 1-11.

Neilson, N. \& Wright, S.

$1995 \quad$ Power and Participatory Development Theory and Practice. Intermediate Technology Publications, London, 1995 , p.p. 1-200.

Oakley, P.

1983
The Monitoring and Evaluation of Participation in Rural Development. For FAO, Rome. Agricultural

Extension and Rural Development Centre, University of Reading, UK.

O'Connor, J.

1987,

Parkin, David

1982

Pokharel, T.P

1980

Poudyal, L.P.

1987

Poudyal, L.P.

1991

Rahman, M.A

1981

Sen, A. 1

987

Shrestha, B.K.

1971

Shrestha, B.P. 1989

Shrestha, D.K. 1981
The Meaning of Crisis: A Theoritical Introduction Basil Blackwell.

Semantic Anthropology; Academic Press, London

People's Participation and Rural Development: A Study of Three Village Panchayats in Gorkha (Kathmandu: Centre for Economic Development and Administration.

Nepal: Project Planning and Implementation Experience under De-Centralization (a Report submitted to the Asian Development Bank), Kathmandu, Nepal (Unpublished).

Experience of Training for De-Centralization Planning in Nepal. Public Administration and Development. International Journal of Training, Research and Practice. Vol 11(2), pp. 171-179.

Participation of the Rural Poor in Development, No. 1, pp. 3-5.

On Ethics and Economics, Blackwell Oxford.

Thakuri of Diyar Gaun. Royal Nepal Academy, Kathmandu, 1971.

Planning and Development in Nepal:, in: Malla, K.P. (Ed., 1989). Nepal: Perspectives on continuity and change. Centre for Nepal and Asian Studies. Tribhuvan, Nepal, pp. 192-213.

Local level Planning in Nepal - Survey, Analysis and General Guidelines. Ministry of Panchayat and Local Development, Kathmandu, Nepal. 
Shepherd, G.

1982

Life Among the Magars. Sahayogi Press,

Kathmandu, pp. 241-247.

Tanner, $\mathrm{P}$.

2001

Samaj: Journal of Sociology and Anthropology.

Volume 1. Tri-Chandra Multiple Campus, Kathmandu, Nepal. P.p. 25-27.

Thapa, T.S.

The Development of Sociology in Nepal. Tribhuvan University. Kathmandu, Nepal.

Toffler, $\mathrm{T}$. 1990

Powershift: Knowledge, Wealth and Violence at the Edge of the 21st Century (3rd ed.). Washington: Bantam Press.

Torre, D.

1989

Empowerment: Structured Conceptualization and Instrument Development. Unpublished doctoral dissertation, Cornell University.

UN Interagency Committee on Integrated Rural Development for Asia and the Pacific.

1990 Participatory Rural Development in Selected Countries, Bangkok, pp. 19-30.

Uphoff, N

1992

Local Institutional Development: An Analytical Source-book with Cases, West Harford, Connecticut: Kumarian Press.

P.Vandergeest and F.Buttel

1988 Marx, Weber, and Development Sociology: Beyond the Impasse., World Development, 16 (6), pp.683695.

Wandersman, A., Florin, P., Rich, R., \& Chavis, D.

1990 Benefits, Costs, Incentive Management and Participation in Voluntary Organizations. Community Psychology.

Yeich, S., \& Levine, R.

1992

Participatory Research's Contribution to a Conceptualization of Empowerment. Journal of Applied Social Psychology, 22, 1894-1909.
Zimmerman, M.

1990

Taking Aim on Empowerment Research: On the Distinction Between Individual and Psychological Conception. American Journal of Community Psychology, 18, 169-177.

Zimmerman, M

1992

Empowerment Theory: Psychological,

Organizational and Community Levels of Analysis.

The Handbook of Community Psycholgoy. ((In J.

Rappaport \& E. Seidman (Eds.), New York: Plenum Press)

Zimmerman, M., \& Rappaport, J.

1988 Citizen Participation, Perceived Control and Psychological Empowerment. Community Psychology. 
1. Rishikeshab Raj Regmi, Professor and Chairperson, Department of Sociology/Anthropology; Ph.D. (Anthropology), University of Calcutta.

2. Kailash Nath Pyakuryal, Professor and Former Chairman and Dean, Institute of Agriculture and Animal Sciences; Ph.D.(Rural Sociology), Michigan State University.

3. Chaitanya Mishra, Professor and Former Chairman; Ph.D. (Sociology), University of Florida.

4. Ganesh Man Gurung, Professor and Former Chairman; Ph.D. (Sociology), Banarus Hindu University.

5. Ram Bahadur Chhetri, Reader, Ph.D. (Anthropology), University of Hawaii.

6. Kiran Dutta Upadhya, Reader, M.S.(Rural Sociology), University of the Philippines (Currently enrolled in the $\mathrm{Ph} . \mathrm{D}$. program in sociology at West Bengal University).

7. Krishna Bahadur Bhattachan, Lecturer and Former Chairman; $\mathrm{Ph} . \mathrm{D}$. (Sociology), University of California, Berkeley.

8. Padam Lal Devkota, Lecturer; Ph.D. (Anthropology) Delhi University.

9. Om Gurung, Lecturer and Former Chairman; Ph.D. (Anthropology ), Cornell University.

10. Phanindreswor Paudel, Lecturer; M.A. (Sociology); Banaras Hindu University.

11. Laya Prasad Uprety, Lecturer; M.A. (Anthropology), Tribhuwan University, M.S. (Social Development), Ateno De Manila University, the Philippines (Currently enrolled in the $\mathrm{Ph}$.D. program in Anthropology at Tribhuvan University, Nepal).

12. Tulsi Ram Pandey, Lecturer; M.A. (Sociology), Tribhuvan University. M.S. (Social Development) Ateno De Manila University, the Philippines (Currently enrolled in the $\mathrm{Ph}$. D. program in Sociology at Delhi University, India).

13. Prabhakar Lal Das, Lecturer; M.A. (Sociology) Bhagalpur University.

14. Bhanu Bhakta Timsina, Lecturer; M.A. (Anthropology), Tribhuvan University.

15. Youba Raj Luitel, Lecturer; M.A. (Sociology), Tribhuvan University, M.S. (Gender studies) at Institute of Social Studies, the Netherlands.

16. Surendra Mishra, Lecturer; M.A. (Sociology), Tribhuvan University.
17. Saubhagya Shah, Lecturer; M.A. (Sociology), Tribhuvan University, Enrolled in the Ph.D. Program in Anthropology at Harvard University.

18. Binod Pokharel, Lecturer; M.A. (Anthropology), Tribhuvan University.

19. Pratibha Gautam, Lecturer; M.A. (Anthropology), Tribhurvan University (On Deputation in Padma Kanya Campus).

20. Keshab Kumar Shrestha, Lecturer; M.A. (Anthropology), Tribhuvan University, (Currently enrolled in the Ph.D. Program in Anthropology at Tribhuvan University).

21. Samira Luitel, Lecturer; Ph.D. (Sociology), Edminton University, Canada.

22. Chinta Mani Pokhrel, Lecturer; M.A.(Anthropology), Tribhuvan University.

\section{PART TIME FACULTY}

23. Dilli Ram Dahal, Professor, Ph.D.(Anthropology), University of Hawii (Part Time from CNAS).

24. Sunita Upreti, (Banstola), M.A. (Sociology), Tribhuvan University

25. Janak Rai, Assistant Lecturer; M.A. (Anthropology), Tribhuwan University (Part Time from Tri-Chandra Campus)

26. Uddav Rai, M.A. (Anthropology), Tribhuvan University, M.S. (Applied Social Research), University of Manchester, London.

27. Suresh Dhakal, M.A. (Anthropology), Tribhuvan University, M.Phill.(Anthropology), University of Bergan, Norway

28. Pasang Sherpa, Assistant Lecturer; M.A. (Sociology), Tribhuvan University (part time from Trichandra Campus)

29. Man Bahadur Khatri, M.A. (Anthropology), Tribhuvan University, M.Phil.(Anthropology), University of Bergan, Norway.

30. Madhu Sudan Sharma, M.A. (Sociology) Tribhuvan University, M.Phil. (Anthropology), University of Bergan.

31. Shambhu Kattel, M.A. (Sociology) Tribhuvan University, M.Phil.(Anthropology), University of Bergan.

\section{ADMINISTRATIVE STAFF}

1. Sulochana Thapa - Assistant Administrator

2. Prem Shrestha - Accountant

3. Krishna Karki - Office Assistant

$4 \quad$ Ram Bhakta Karki- Peon. 


\section{OCCASIONAL PAPERS PUBLICATIONS}

\section{VOL.1}

1. Nepal School of Sociology/Anthropology Dor Bahadur Bista

2. Sociology and Anthropology Curriculum and the Needs of Nepal Krishna Bahadur Bhattachan.

3. "Romanticism" and Development" in Nepalese Anthropology James F. Fisher

4. Migration, Adaptation, and Socio-Cultural Change : The Case of the Thakalis in Pokhara

Ram Bahadur Chhetri.

5. Native Strategies for Resource Management

Om Prasad Gurung

6. Natural Causes and Processes of Poverty in Micro Settings Tulsi Ram Pandey

7. Factors Associated with Occupational Sociolization in Rural Nepal

Kiran Dutta Upadhyay

8. Development and Underdevelopment : A Preliminary Sociological Perspective

Chaitanya Mishra

VOL. 2

1. Sociology and Anthropology : An Emerging Field of Study in Nepal Om Gurung

2. The past and Future of Sociology in Nepal

Bishnu Bhandari

3. Some Sociological Reflections on Development in the Eastern Himalayas

Gopal Singh Nepali

4. Economic Modernization in a Chepang Village in Nepal Ganesh Man Gurung

5. Culture and Resource Management for Subsistence : An Anthropological Perspective

Bhanu Timseena

6. A Socio-economic profile of the Porters in the Central Mid-Hills of Nepal

Kiran Dutta Upadhyay

7. Employment, Working Conditions and Mode of Living : The Case of Nepali Watchmen in Bombay
Television and the Child in Nepal : An Assessment of Viewing Patterns

Dyuti Baral

9. Mercantilism and Domestic Industry in West-Central Nepal Significance for Anthropological Study of the Community Stephen L. Mikesell and Jamuna Shrestha

Vol. 3

1. Forestry and Farming System in the Mid-Hills of Nepal Kiran Dutta Upadhyay

2. Socio-Economic and Cultural Aspects of Aging in Nepal

Rishikeshab Raj Regmi

3. Religion, Society and State in Nepa

Dipak Raj Pant

4. Community Development as Strategy to Rural Development

Kailash Pyakuryal

5. National Integration in Nepal

Ganesh Man Gurung and Bishnu Bhandari

6. The failure of Confidence Mechanism

Tulsi Ram Pandey

7. Building a New American Academic Anthropology Tom Cox

8. Afro-American Sociologists and Nepali Ethnography Stephen L. Mikesel

9. Case Studies on Domestic Servants: Reflection on Rural Poverty

VOL. 4 Saubhagya Shah

1. Anthropology, Development and Public Policy

Gerald D. Berreman

2. Development Issues Raised during the "People's Movement" of 1990 Krishna B. Bhattachan

3. Anthropological Perspectives on Grassroots Development in Nepal

Padam Lal Devkota

4. Deforestation and Rural Society in the Nepalese Terai

Rishikeshab Raj Regm

5. The Current Socio-Economic Status of Untouchables in Nepal

Thomas Cox

6. Group Process for People's Participation in Rural Nepal : Reflection from a Micro Level Study

Youba Raj Luitel

7. Sherpa Buddhists on a Regional Pilgrimage : The Case of Maratika Cave a Halase

Eberhard Berg

8. Book Review

Hemant Humar Jha 


\section{NOTES TO CONTRIBÜTORS}

VOL. 5

1. Ethnicity and Nationalism in the Nepali Context

A Perspective from Europe

Uwe Kievelitz

2. The issue of National Integration in Nepal

An Ethnoregional Approach

Krishna B. Bhattachan

Kailash N. Pyakuryal

3. Bheja as a Strategic Cultural Convention

Community Resource Management in the Barha Magarat

Suresh Dhakal

4. The Rajbanshis of Rajgadh

Community Adaptation in the Enviroment of Eastern Terai

Hari P. Bhattarai

5. Kurma, Kola, and Kuri as Community Concepts

Patrilineage, Deities, and Inside-Outside Dichotomy among the Rana

Tharus

Ganesh M. Gurung

Tove C. Kittelson

VOL. 6

1. Forest, People's Participation and Conflicts in Nepal

Dr. Rishikeshab Raj Regmi

2. Restoration of Democracy and People's Empowerment in Nepal

Prof. Kailash N. Pyakuryal

3. People-centered Development in Nepal: an Innovative Approach

Dr. Padam Lal Devkota

4. Functions of an Organization in a Indigenous Irrigation System: A Case Study from a Hill Village in Nepal

Laya Prasad Uprety

5. An Analysis of The Rural Poverty From People's Perspectives: A Case Study from Amarpur VDC of Panchthar District

Binod Pokharel

6. Environmental Pollution and Awareness in Pokhara City: A Sociological Perspective

Dr. Biswo Kalyan Parajuli

7. An Anthropological Perspective on Shifting Cultivation: A Case Study of Khoriya Cultivation in the Arun Valley of Eastem Nepal Suresh Dhakal

8. Social Engineering Approach to Air Quality Challenge: The Case of Kathmandu

Ramesh C. Arya
Occasional Papers in Sociology and Anthropology publishes articles, original research reports, review articles, book reviews, dissertation abstracts, professional announcements, and other information of interest in the areas of the sociology and anthropology of Nepal and other Himalayan regions. Both the Nepalese and foreign scholars may submit their articles.

Materials submitted should be in English. Authors must take full responsibility for the originality, contents, and opinions expressed in their taktes. copyrighted material which is to be reproduced in the articles must be suitably acknowledged.

Contributors are requested to send, if possible, their materials on computer floppy disks using IBM compatible word processing programs. They may, however, send copy of the manuscript separately. The text, notes, and references should be typed double -spaced. All pages should be numbered. The title of the paper, author's name, affiliations, and complete address should appear on the first page.

The anthropological style of referencing is preferred. Texts should refer to notes numbered consecutively. All notes and footnotes should appear at the end of the paper. Book reviews should not, however, contain footnotes. All references should be incorporated in the text itself.

Citation in the text should include the author's surname, year of publication, and page number. e.g. : (Sorokin, 1978:49). If the publication to be cited is authored by more than two persons, then use the sumame of the first author, to be followed by et al. If the same reference is cited more than once continuously, use ibid. after citing the full reference once, but giving the relevant page number if it is different.

Entries for the bibliographical list should follow the following order : author's name (sumame, followed by full first name or initials), year of publication, the title of publication along with its edition number, place of publication, and publisher's name. If the reference for an article from an edited book, then give the name of the author as suggested above, year of publication, the title of the article, the title of the book, editor's name, place of publication, and publisher's name; e.g. Greenwold Stephen, 1978. "The Role of the Priest in Newar Society". Himalayan Anthropology. ed. James Fisher. The Hague : Mouton

If the reference is from a periodical, give the name of the author as suggested above, year of publication, the title of the periodical with its volume number, and page number : e.g : Gray John, N. 1980. "Hypergamy, Caste and Kinship among the Chhetris of Nepal", Contributions to Indian Sociology, 14: 1-34.

If the year and the place of publication are missing use n.d. and n.p. respectively. The bibliographical list should preferably include only the works cited Use double quote marks ( " ") while quoting sentences and single quotes (' ') for a single work/phrase. Use spellings as followed in the New Webster Dictionary or Oxford Dictionary. Contributors are requested to maintain consistency throughout their articles. to :
The Chairperson

Central Department of Sociology/Anthropology

Tribhuvan University

Kirtipur, Kathmandu 